\title{
Methanol Extract of Peltophorum pterocarpum Stem Bark Has Antimalarial Activity and Normalizes Biochemical Changes Induced by Plasmodium berghei Infection
}

\author{
Osmund C. Enechi ${ }^{1} \quad$ Innocent U. Okagu ${ }^{1 *} \quad$ Joseph C. Ndefo ${ }^{2} \quad$ Christian C. Chibuogwu ${ }^{1,3}$ \\ Christian C. Amah ${ }^{1} \quad$ Amarachi G. Obinyima ${ }^{1} \quad$ Linda Kalu $^{1} \quad$ Justin Okakpu ${ }^{1}$ Lydia N. Amoke ${ }^{1}$ \\ 1.Department of Biochemistry, University of Nigeria, Nsukka, Enugu State, Nigeria \\ 2.Department of Science Laboratory Technology, University of Nigeria, Nsukka, Enugu State, Nigeria \\ 3.Institute for Drug-Herbal Medicine-Excipient Research and Development, University of Nigeria, Nsukka. \\ Enugu State, Nigeria
}

\begin{abstract}
This study evaluated the antimalarial, haematological and biochemical status of Plasmodium berghei Anka 65infected mice treated with methanol extract of Peltophorum pterocarpum stem bark (MEPT). The acute toxicity profile and phyto-constituents were also evaluated. Thirty mice were divided into 6 groups of 5 mice each. Group 1 served as normal control and received distilled water only. Group 2 was parasitized and untreated. Groups 3-5 were parasitized and treated with 200, 400 and $600 \mathrm{mg} / \mathrm{kg}$ b.w. body weight of MEPT respectively. Group 6 was parasitized and treated with $28 \mathrm{mg} / \mathrm{kg}$. b.w. of arthemeter/lumenfantrin combination. Malaria parasitemia were monitored on treatment days 0-3. Antioxidant, liver, kidney and lipid peroxidation status were determined using classical methods 5 days post-treatment. There were dose-dependent reductions in malaria parasitemia percentages of groups 3-5 that are comparable with group 6. In addition, there were dose and duration-dependent increases in malaria chemo-suppression in groups 3-5. The existence of oxidative stress, lipid peroxidation, and kidney and liver dysfunctions were observed in group 2 when compared with group 1. Treatment of groups 3-5 with MEPT and group 6 with arthemeter/lumenfantrin for 4 days restored the biochemical anomalies induced by malaria. The extract was tolerable up to $5,000 \mathrm{mg} / \mathrm{kg} \mathrm{b}$.w. of MEPT. The presence of flavonoids, alkaloids, saponins, tannins, steroids, carotenoids, glycosides, anthraquinones, terpenoids and anthocyanins were detected in high amounts while phenols was detected in low amount in MEPT. These suggest that MEPT possesses antimalarial activity and normalizes malaria-modified biochemical changes. These effects might be attributed to its bioactive constituents.
\end{abstract}

Keywords: malaria, Peltophorum pterocarpum, phytochemicals, toxicity, biochemical dysfunctions

DOI: $10.7176 /$ ALST/73-05

Publication date: April 30 2019

\section{Introduction}

Morbidity and mortality to malaria has remained unacceptably high globally and majority of individuals who die from malaria are infants, children and pregnant women living in sub-Saharan Africa and Asia (Onaku et al., 2011; WHO, 2018). Plasmodium species (the causative agent of malaria) affect some organs in the body such as liver, kidney and brain causing dysfunctions associated with uncontrolled malaria condition (Dzeing-Ella et al., 2010). The severity of malaria infection can be determined by measuring the parasite density, haematological and biochemical status (such as antioxidant, lipid peroxidation, renal and hepatic status). Clinical manifestation of renal involvement in human malaria is associated with infection by $P$. falciparum and Plasmodium malariae (Naqvi et al., 2003), and may be responsible for an immune complex mediated glomerular disease leading to nephrotic syndrome. Other renal-associated complications include urinary sediment anomalies, proteinuria, electrolyte imbalance, and acute renal failure (ARF) with metabolic acidosis (Padhi and Mishra, 2012). Also, renal tubular variations are reported in $P$. falciparum infection such mild and acute tubular necrosis (ATN) and ARF accompanied by frequent oliguria and hypercatabolism (Gomes et al., 2011). ARF can be diagnosed by elevated serum creatinine and urea levels (Uzuegbu, 2011; Padhi and Mishra, 2012). The sudden increase in the urea level and imbalance in the electrolyte levels such as sodium, potassium, bicarbonate, and chloride in patients suffering from malaria could serve as indicators for kidney dysfunction (Jasani et al., 2012). Generally, malaria is such a serious issue because it goes with several complications such as oxidative stress (Chikezie and Okpara, 2013; Oyewolea et al., 2014), hypoglycemia and hyperinsulinaemia (Elased and Playfair, 1994), haematological aberrations (Akin-Osanaiye et al., 2013; Bakhubaira, 2013).

Liver dysfunction is a common complication that usually occurs in malaria infection. Studies reported a sudden increase in serum activities of liver marker enzymes in malaria infected individuals as an indication of liver dysfunction (Jarikre et al., 2001; Onyesom and Onyemakonor, 2011). The sporozoite invasion of hepatocytes during the exo-erythrocytic stage of malaria parasite life cycle contributes immensely to liver dysfunction in malaria (Onyesom, 2012). The presence of sporozoites in the liver during exo-erythrocytic as well 
as accumulation of haemozoin in the liver during erythrocytic stages of malaria parasite life cycle induces immune-mediated damages to the hepatocytes. This causes leakage of parenchymal and membranous enzymes of the liver into general circulation, which might be responsible for the increase in serum activities of these liver marker enzymes (Burtis and Ashwood, 2001). In addition, the activities of liver marker enzymes and level of creatinine has been shown to be correlated with malaria parasite density and hence, severity of malaria infection (Onyesom and Onyemakonor, 2011). As a result of high level of complication and death of children and pregnant women due to malaria infection, there is need to evaluate the extent of renal and hepatic dysfunctions in malaria using animal model so that there will be proper management of malaria infection and its associated complication (Ogbadoyi and Tsado, 2009). The challenges posed to man by malaria are worsened by the absence of malaria vaccine, inaccessibility and unavailability of effective antimalarials; the antimalarial drugs available are expensive and toxic. In addition, there are existence and spread of drug-resistant Plasmodium species (Saotoing et al., 2011). This necessitates a continuous effort to search for new drugs and alternatives; one of which is the search for plant materials with antimalarial potentials and ameliorative effect on malarial-related complications. In addition, there are also needs to add more variety of antimalarial to existing ones to provide drugs for individuals who do not tolerate the currently-available antimalarial drugs.

Peltophorum pterocarpum belongs to the family Leguminosae and is a native to tropical Southeastern Asia and an ornamental tree widely distributed around the world including India and Nigeria. Different parts of $P$. pterocarpum are used in the treatment of diseases such as stomatitis, insomnia, constipation and ringworm by traditional healers. The flower extract is used to induce sleep and treat insomnia. Its bark is used as medicine for dysentery, as eye lotion, embrocation for pains and sores. Traditional healers in Southeastern Nigeria use extracts of the plant stem bark to treat malaria (Enechi et al., 2016). Scientific reports recorded that $P$. pterocarpum extracts exhibit high free radicals scavenging activity (Jain et al., 2012), liver protective activity (Biswas et al., 2010), hypoglycemic activity (Manaharan et al., 2011), anti-anaemic effect (Enechi et al., 2016), antibacterial effect (Jagessar et al., 2007; Ravikumar and Subbu-Raltinan, 2009) and histoprotective effect (Karunai et al., 2012). It is therefore necessary to evaluate in addition to its antimalarial activities, the ameliorative effects of methanol extract of P. pterocarpum stem bark on Plasmodium berghei-Anka 65-induced oxidative stress, and haematological, kidney and liver abnormalities in mice, in order to scientifically validate the folkloric use of the plant in the treatment of malaria and its associated complications.

\section{Materials and methods}

\subsection{Collection, authentication and extraction of plant material}

Fresh stem bark of P. pterocarpum was collected from a Habitat in Nsukka, Enugu State, Nigeria and was authenticated at the Herbarium of the Department of Plant Science and Biotechnology, University of Nigeria, Nsukka, Enugu State, Nigeria. Stem bark of P. pterocarpum $(2.0 \mathrm{~kg})$ was washed, chopped into small pieces, airdried for 14 days and powdered mechanically. One kilogram $(1.0 \mathrm{~kg})$ of ground coarse sample was macerated in 5.5 litres of methanol (BDH, England) for $72 \mathrm{~h}$ with interval stirring. The suspension was filtered and filtrate was concentrated under reduced pressure and dried using a rotary evaporator at $45^{\circ} \mathrm{C}$. The dark-brown concentrate (henceforth called methanol extract of $P$. pterocarpum stem back- MEPT) was stored in a dark sterile air-tight container at $4-8^{\circ} \mathrm{C}$ until used. The percentage yield of the extract was $28.15 \%$.

\subsection{Acute toxicity study on MEPT}

The acute toxicity profile was assessed by adopting the method of Lorke (1983). This study was carried out in two phases and involved a total of 18 albino mice. In the first phase, 9 mice were grouped into 3 groups of 3 mice each and were orally administered 10,100 and $1000 \mathrm{mg} / \mathrm{kg}$ b.w. of MEPT respectively. The mice were observed for $24 \mathrm{~h}$ for sign of toxicity such as nervousness, dullness, incoordination and/or death. In the second phase, 3 groups of 3 mice each orally received 1600, 2900 and $5000 \mathrm{mg} / \mathrm{kg} \mathrm{b.w.} \mathrm{respectively.} \mathrm{The} \mathrm{mice} \mathrm{were}$ monitored for $24 \mathrm{~h}$ as above and observations were recorded.

\subsection{Management of Experimental Animals and Parasite Inoculation}

Experimental animal models used for the study were male albino mice of weight 30-35 g. The mice were obtained from the Faculty of Veterinary Medicine, University of Nigeria, Nsukka. Before the experiment, the mice were acclimatized under standard laboratory condition in the animal farm of the Department of Biochemistry, University of Nigeria, Nsukka for 2 weeks with free access to water and rodent chow ad libitum. The experimental procedures followed the institutional, national and international (Pub No.85-23, revised 1985) Ethical Guidelines for the Care and Use of Laboratory Animals.

Donor mouse blood infected with the P. berghei was obtained from the Department of Parasitology, Faculty of Veterinary Medicine, University of Nigeria, Nsukka and was used for inoculum preparation. Blood sample from the donor mouse was diluted serially in Alsever's solution so that every $0.2 \mathrm{ml}$ of the suspension will contain about $1 \times 10^{7}$ infected red blood cells (RBCs). Mice in groups 2-6 were each inoculated with $0.2 \mathrm{ml}$ 
suspension intraperitoneally to initiate infection. Malaria infection was confirmed $72 \mathrm{~h}$ post inoculation (day 0 ). All the mice were divided into 6 groups of 5 mice and treated orally with extract and standard drugs as thus: Group 1 served as normal uninfected mice treated with $1 \mathrm{ml} / \mathrm{kg}$ distilled water (normal control). Group 2 served as malaria control (parasitized and untreated mice). Groups 3, 4 and 5 were parasitized mice treated with 200, 400 and $600 \mathrm{mg} / \mathrm{kg} \mathrm{b.w.} \mathrm{of} \mathrm{MEPT} \mathrm{respectively} \mathrm{(doses} \mathrm{previously} \mathrm{used} \mathrm{by} \mathrm{Enechi} \mathrm{et} \mathrm{al.} \mathrm{(2016)} \mathrm{were} \mathrm{adopted).}$ Group 6 were parasitized mice treated with $28 \mathrm{mg} / \mathrm{kg}$. b.w. of arthemeter/lumenfantrin. The level of parasitaemia was determined on days $0,1,2$, and 4 . On day 9 (5 days post-treatment), after an overnight fasting, the experimental mice were sacrificed and blood samples were collected by ocular puncture into anticoagulated and plain tubes. The samples in plain tube were allowed to cloth for $15 \mathrm{~min}$ at room temperature after which it was centrifuges at $4000 \mathrm{rpm}$ for $10 \mathrm{~min}$. The supernatant (serum) was subjected to biochemical analyses. Samples collected in anticoagulated tubes were used for haematological analysis.

\subsection{Determination of parasitaemia level}

The levels of parasitaemia in the experimental mice were determined haematologically, using microscopic technique of Peters (1967) with slight modification. Thick blood smears were collected daily from tail blood, stained with Giemsa's stain and examined under low powered microscope (x 10 resolution) to determine the parasitaemia level. The percentage parasitaemia was determined by counting the parasitized red blood cells out of RBCs in random fields of the microscope:

$$
\% \text { Parasitaemia }=\frac{\text { Number of parasitized RBC }}{\text { Total number of RBC counted }} \times 100
$$

2.5 Determination of haematological and biochemical parameters

Already established methods were adopted for the determination of haematological and biochemical status of the experimental mice. The parameters analyzed and methods used include: The cyanomethaglobin and haemocytometry methods of Ochei and Kolhatkar (2008) were used to determine the haemoglobin concentration, and red blood cells (RBC), white blood cells (WBC) and platelet (PLT) counts respectively. The activities of catalase (CAT) (Aebi, 1984), superoxide dismutase (SOD) (Fridovich, 1983), glutathione peroxidase (GPx) (Paglia and Valentine, 1962), aspartate aminotransferase (AST) and alanine aminotransferase (ALT) (Reitman and Frankel, 1957), and alkaline phosphatase (ALP) (Kochmar and Moss, 1976) were detected. Others include concentrations of glutathione (Habig et al., 1974), vitamins A, C (Goodhart and Shils, 1973), and E (Desai, 1984), malondialdehyde (MDA) (Wallin et al., 1993) and total bilirubin (Jendrassik and Grof, 1938). The determination of urea level in serum was done using the Urease Berthelot method of Fawcett and Scott (1960). Serum creatinine level was determined based on the Jaffe's alkaline picrate reaction using direct endpoint method of Henry (1974). The enzymatic method outlined by Milena et al. (2003) was used for the determination of uric acid level.

2.6 Phytochemical screening of the extract

The methods earlier reported by Harbone (1973) and Trease and Evans (1989) were adopted in this study to screen for the presence of flavonoids, alkaloids, saponins, tannins, steroids, carotenoids, glycosides, anthraquinones, terpenoids, anthocyanins and phenols in the extract.

\subsection{Statistical analysis}

One-way analysis of variance (ANOVA) was employed to compare means across the test and control groups. Primary data from the laboratory were analyzed in IBM Statistical Product and Service Solutions (SPSS) software, version 16 . Mean values with $\mathrm{p}<0.05$ were considered statistically significant.

\section{Results}

3.1 Acute toxicity profile of MEPT

The acute toxicity test of MEPT showed that the extract is tolerable; there was neither mortality nor sign of toxicity at doses up to $5,000 \mathrm{mg} / \mathrm{kg}$ per body weight of the extract (Table 1). This result implies that the $\mathrm{LD}_{50}$ is above $5,000 \mathrm{mg} / \mathrm{kg}$ b.w.

3.2 Effect of MEPT on the malaria parasitaemia and malaria parasite chemo-suppression

As shown in Table 2, mice in group 2 (infected and untreated) had a significantly $(\mathrm{p}<0.05)$ higher malaria parasitaemia compared with animals in control, and infected and treated groups (On day 1, 24 hr post-treatment). From days $0-3$, the percentage malaria parasitaemia of mice in group 2 were increased significantly $(\mathrm{p}<0.05)$ while those of animals in groups $2-6$ had significant $(p<0.05)$ reduction. This implies that infection with malaria increased the malaria parasitaemia in mice if left untreated as seen in group 2 compared to group 1. Also, the 
reduction in malaria parasitaemia in mice treated with MEPT was dose-dependent and was comparable with standard drug (arthemeter/lumenfantrin). Similarly, there was a dose and duration-dependent increase in percentage malaria chemo-suppression in malaria-parasitized and extract-treated mice.

Table 1: The acute toxicity profile of MEPT

\begin{tabular}{|c|c|c|}
\hline Group & Dosage ( in mg/kg b.w) & Mortality \\
\hline \multicolumn{3}{|c|}{ Phase I } \\
\hline Group 1 & 10 & $0 / 3$ \\
\hline Group 2 & 100 & $0 / 3$ \\
\hline Group 3 & 1000 & $0 / 3$ \\
\hline \multicolumn{3}{|c|}{ Phase II } \\
\hline Group 1 & 1600 & $0 / 3$ \\
\hline Group 2 & 2900 & $0 / 3$ \\
\hline Group 3 & 5000 & $1 / 3$ \\
\hline \multicolumn{3}{|c|}{ Median Lethal dose $\left(\mathrm{LD}_{50}\right)=3807.89 \mathrm{mg} / \mathrm{kg} \mathrm{b} . \mathrm{w}$} \\
\hline
\end{tabular}

Table 2: Effect of MEPT on malaria parasitaemia and malaria parasite chemo-suppression

\begin{tabular}{|c|c|c|c|c|c|c|c|}
\hline $\begin{array}{l}\text { Groups/ } \\
\text { Duration }\end{array}$ & $\begin{array}{c}\text { Day } 0 \\
\text { (\%) }\end{array}$ & $\begin{array}{c}\text { Day } 1 \\
(\%)\end{array}$ & $\begin{array}{c}\text { Day } 2 \\
(\%)\end{array}$ & $\begin{array}{c}\text { Day } 3 \\
(\%)\end{array}$ & $\begin{array}{c}\text { Day } 1 \text { Chemo- } \\
\text { suppression } \\
(\%) \\
\end{array}$ & $\begin{array}{c}\text { Day } 2 \text { Chemo- } \\
\text { suppression } \\
(\%) \\
\end{array}$ & $\begin{array}{c}\text { Day } 3 \text { Chemo- } \\
\text { suppression } \\
(\%) \\
\end{array}$ \\
\hline Group 1 & $0.00 \pm 0.00$ & $0.00 \pm 0.00$ & $0.00 \pm 0.00$ & $0.00 \pm 0.00$ & - & - & - \\
\hline Group 2 & $46.50 \pm 5.01^{\mathrm{a}}$ & $76.00 \pm 2.16^{\mathrm{a}}$ & $83.50 \pm 3.70^{\mathrm{a}}$ & $87.75 \pm 5.56^{\mathrm{a}}$ & - & - & - \\
\hline Group 3 & $48.00 \pm 10.12^{\mathrm{a}}$ & $41.50 \pm 3.10^{b}$ & $39.25 \pm 7.27^{b}$ & $30.00 \pm 6.27^{b}$ & $24.75 \pm 6.23^{b}$ & $20.71 \pm 4.42^{\mathrm{a}}$ & $37.37 \pm 2.12^{\mathrm{a}}$ \\
\hline Group 4 & $57.25 \pm 7.18^{\mathrm{ab}}$ & $40.50 \pm 6.03^{c}$ & $35.00 \pm 6.06^{\mathrm{bc}}$ & $25.25 \pm 4.57^{\mathrm{c}}$ & $32.75 \pm 3.17^{\mathrm{c}}$ & $45.85 \pm 1.91^{b}$ & $57.64 \pm 3.36^{\mathrm{b}}$ \\
\hline Group 5 & $52.40 \pm 5.08^{\mathrm{ab}}$ & $38.25 \pm 7.63^{c}$ & $27.25 \pm 4.27^{\mathrm{c}}$ & $20.00 \pm 3.16^{\mathrm{d}}$ & $34.05 \pm 2.43^{c}$ & $53.01 \pm 2.20^{\mathrm{c}}$ & $70.69 \pm 1.62^{c}$ \\
\hline Group 6 & $56.50 \pm 5.80^{\mathrm{b}}$ & $48.50 \pm 6.19^{c}$ & $26.25 \pm 3.30^{c}$ & $15.25 \pm 2.30^{\mathrm{d}}$ & $19.50 \pm 1.84^{\mathrm{a}}$ & $56.43 \pm 3.43^{c}$ & $74.69 \pm 4.28^{c}$ \\
\hline
\end{tabular}

Data are mean \pm standard deviation $(\mathrm{SD})(\mathrm{n}=5)$. Values with different superscript down the column are statistically significant at $\mathrm{p}<0.05$.

3.3 Effects of MEPT on the haematological indices of malaria-infected mice

The results of the packed cell volume (PCV), haemoglobin $(\mathrm{HB})$ concentration, red blood cell (RBC), white blood cell (WBC) and platelets count of experimental animals are shown in Table 3. Mice infected with $P$. berghei and untreated (group 2) have significantly $(\mathrm{p}<0.05)$ lower PCV level, Hb concentration, RBC, WBC and PLT counts when compared with normal control. Treatment of parasitized mice with graded doses of extract (groups 4-6) and artesunate (group 3) significantly $(\mathrm{p}<0.05)$ increased all the haematological parameters towards normal when with group 2.

Table 3: Effects of MEPT on the haematological indices of malaria parasitized mice

\begin{tabular}{|c|c|c|c|c|c|}
\hline Groups & PCV (\%) & HB $(\mathbf{g} / \mathbf{L})$ & $\mathbf{W B C ~}_{\left(\mathbf{m m}^{-3}\right)}$ & RBC $\left._{(\mathbf{X 1 0}}^{\mathbf{6}} / \mathbf{L}\right)$ & Platelets $\left(\mathbf{X 1 0}^{\mathbf{9}} / \mathbf{L}\right)$ \\
\hline Group 1 & $40.75 \pm 3.20^{\mathrm{b}}$ & $13.63 \pm 1.11^{\mathrm{b}}$ & $6200 \pm 495.31^{\mathrm{b}}$ & $236.25 \pm 4.79^{\mathrm{e}}$ & $130.00 \pm 5.89^{\mathrm{c}}$ \\
\hline Group 2 & $28.50 \pm 2.38^{\mathrm{a}}$ & $9.38 \pm 0.75^{\mathrm{a}}$ & $5800 \pm 565.69^{\mathrm{a}}$ & $151.25 \pm 8.54^{\mathrm{a}}$ & $99.50 \pm 4.20^{\mathrm{a}}$ \\
\hline Group 3 & $37.75 \pm 1.71^{\mathrm{b}}$ & $12.38 \pm 0.48^{\mathrm{b}}$ & $6075 \pm 170.78^{\mathrm{b}}$ & $190.00 \pm 9.13^{\mathrm{b}}$ & $117.00 \pm 2.58^{\mathrm{b}}$ \\
\hline Group 4 & $38.75 \pm 1.50^{\mathrm{b}}$ & $12.63 \pm 0.48^{\mathrm{b}}$ & $6600 \pm 230.94^{\mathrm{b}}$ & $216.25 \pm 4.79 \mathrm{~d}$ & $147.00 \pm 9.75^{\mathrm{d}}$ \\
\hline Group 5 & $42.75 \pm 1.89^{\mathrm{b}}$ & $14.13 \pm 0.75^{\mathrm{b}}$ & $7850 \pm 424.70^{\mathrm{c}}$ & $228.25 \pm 6.24^{\mathrm{e}}$ & $210.75 \pm 3.77^{\mathrm{e}}$ \\
\hline Group 6 & $40.50 \pm 1.00^{\mathrm{b}}$ & $13.25 \pm 0.50^{\mathrm{b}}$ & $8400 \pm 163.30^{\mathrm{d}}$ & $205.00 \pm 7.07^{\mathrm{c}}$ & $145.00 \pm 3.83^{\mathrm{d}}$ \\
\hline
\end{tabular}

Data represent mean \pm standard deviation $(\mathrm{SD})(\mathrm{n}=4)$. Values with different superscripts are considered significantly different at $\mathrm{p}<0.05$. MEPT $=$ methanol extract of $P$. pterocarpum stem bark

3.4 Effects of MEPT on antioxidant and lipid peroxidation status of parasitized mice

Malaria infection significantly $(p<0.05)$ reduced the activities of antioxidant enzymes $(G P x$, CAT and SOD) of parasitized and untreated mice (group 2) when compared with mice in group 1 (normal control). Treatment of parasitized mice with extract and standard drug (groups 3, 4, 5 and 6 respectively) ameliorated the reduced antioxidant activities when compared to the mice in group 2. Similarly, malaria parasitized and untreated mice (group 2) had significantly $(\mathrm{p}<0.05)$ lower concentrations of antioxidant vitamins (vitamins $\mathrm{A}, \mathrm{C}$ and $\mathrm{E}$ ) when compared with those of group 1. However, treatment of parasitized mice with methanol extract and standard drug significantly $(\mathrm{p}<0.05)$ elevated the concentrations of antioxidant vitamins towards normal control mice when compared to those of infected and untreated (Table 4). In the same vein, infection of mice with malaria parasites significantly $(p<0.05)$ reduced the glutathione $(G S H)$ concentration of mice in group 2 when compared to those of group 1. Meanwhile, there were significantly $(\mathrm{p}<0.05)$ higher GSH concentrations in parasitized and extract- and standard drug-treated mice when compared with those of mice in group 2. On the other hand, parasitized and untreated mice had significantly $(\mathrm{p}<0.05)$ higher malondialdehyde (MDA) concentrations compared with those of mice in group 1. Malaria parasitized and extract- and standard drug-treated mice had 
lower MDA concentration when compared with those of mice in group 2. There was no significant $(p>0.05)$ difference among the MDA levels of mice in groups 1, 3, 4, 5 and 6 which mean that the extract was able to restore the lipid peroxidation level to normal (Table 4).

3.5 Effects of MEPT on the liver and kidney status of parasitized mice

Malaria parasitized and untreated mice (group 2) had significantly $(\mathrm{p}<0.05)$ higher activities of liver function enzymes (ALT, AST and ALP) and concentration of total bilirubin when compared with those of group 1 . However, treatment of parasitized mice (groups 3-6) with methanol extract and standard drug significantly $(p<0.05)$ decreased the activities of liver function enzymes (ALT, AST and ALP) and concentration of total bilirubin when compared to those of infected and untreated (Table 4). It was also observed that malaria parasitized and untreated mice (group 2) had significantly $(\mathrm{p}<0.05)$ higher renal function markers (creatinine, urea and uric acid) concentrations when compared with those of group 1. However, treatment of parasitized mice with methanol extract and standard drug (groups 3-5 and 6 respectively) significantly $(\mathrm{p}<0.05)$ decreased the concentrations of renal function markers (creatinine, urea and uric acid) when compared to the infected and untreated mice (group 2) (Table 5).

Table 4: Effects of MEPT on the antioxidant and lipid peroxidation status of parasitized mice

\begin{tabular}{|c|c|c|c|c|c|c|c|c|}
\hline \multirow[t]{2}{*}{ Groups } & \multicolumn{3}{|c|}{ Antioxidant Enzymes Activities (IU/I) } & \multicolumn{3}{|c|}{ Antioxidant Vitamins Concentrations } & \multicolumn{2}{|c|}{ Lipid peroxidation } \\
\hline & $\begin{array}{l}\text { Glutathione } \\
\text { Peroxidase }\end{array}$ & Catalase & $\begin{array}{c}\text { Superoxide } \\
\text { Dismutase }\end{array}$ & $\begin{array}{c}\text { Vitamin A } \\
(\mathrm{mg} / \mathrm{dl})\end{array}$ & $\begin{array}{c}\text { Vitamin C } \\
(\mathrm{mmol} / \mathrm{l})\end{array}$ & $\begin{array}{c}\text { Vitamin E } \\
(\mathrm{mmol} / \mathrm{l})\end{array}$ & $\begin{array}{c}\text { GSH } \\
(\mathrm{mmol} / \mathrm{l})\end{array}$ & $\begin{array}{c}\text { MDA } \\
(\mathrm{mmol} / \mathrm{l})\end{array}$ \\
\hline Group 1 & $17.05 \pm 0.67^{\mathrm{b}}$ & $2.78 \pm 0.19^{b}$ & $11.05 \pm 0.13^{\mathrm{c}}$ & $18.88 \pm 1.47^{\mathrm{b}}$ & $4.85 \pm 0.37^{\mathrm{b}}$ & $0.15 \pm 0.01^{\mathrm{b}}$ & $1.23 \pm 0.03^{\mathrm{b}}$ & $4.68 \pm 0.86^{\mathrm{b}}$ \\
\hline Group 2 & $6.46 \pm 1.41^{\mathrm{a}}$ & $1.82 \pm 0.10^{\mathrm{a}}$ & $8.83 \pm 0.60^{\mathrm{a}}$ & $11.41 \pm 0.78^{\mathrm{a}}$ & $3.85 \pm 0.64^{\mathrm{a}}$ & $0.09 \pm 0.00^{\mathrm{a}}$ & $1.05 \pm 0.02^{\mathrm{a}}$ & $7.75 \pm 1.44^{\mathrm{a}}$ \\
\hline Group 3 & $18.68 \pm 1.16^{\mathrm{b}}$ & $2.49 \pm 0.48^{\mathrm{b}}$ & $10.30 \pm 0.34^{\mathrm{b}}$ & $18.65 \pm 0.74^{\mathrm{b}}$ & $5.03 \pm 0.57^{\mathrm{bc}}$ & $0.13 \pm 0.01^{\mathrm{b}}$ & $1.12 \pm 0.05^{\mathrm{b}}$ & $5.15 \pm 0.13^{\mathrm{b}}$ \\
\hline Group 4 & $19.47 \pm 0.41^{\mathrm{b}}$ & $2.90 \pm 0.37^{b}$ & $10.68 \pm 0.17^{\mathrm{b}}$ & $19.01 \pm 1.04^{\mathrm{b}}$ & $5.55 \pm 0.37^{\mathrm{bc}}$ & $0.13 \pm 0.01^{\mathrm{b}}$ & $1.39 \pm 0.04^{\mathrm{c}}$ & $4.53 \pm 0.26^{\mathrm{b}}$ \\
\hline Group 5 & $21.49 \pm 1.58^{\mathrm{c}}$ & $2.73 \pm 0.58^{b}$ & $11.65 \pm 0.55^{\mathrm{c}}$ & $20.39 \pm 0.70^{\mathrm{b}}$ & $6.90 \pm 0.32^{\mathrm{c}}$ & $0.14 \pm 0.01^{\mathrm{b}}$ & $1.86 \pm 0.04^{\mathrm{d}}$ & $4.40 \pm 0.36^{\mathrm{b}}$ \\
\hline Group 6 & $17.36 \pm 1.17^{\mathrm{b}}$ & $2.72 \pm 0.23^{b}$ & $10.20 \pm 0.55^{\mathrm{b}}$ & $18.83 \pm 1.22^{\mathrm{b}}$ & $5.83 \pm 0.40^{\mathrm{bc}}$ & $0.14 \pm 0.01^{\mathrm{b}}$ & $1.41 \pm 0.09^{\mathrm{c}}$ & $4.68 \pm 0.17^{\mathrm{b}}$ \\
\hline
\end{tabular}

Data were mean \pm standard deviation $(\mathrm{SD})(\mathrm{n}=5)$. Values with different superscripts down the column are statistically significant at $\mathrm{p}<0.05 . \mathrm{GSH}=$ Glutathione $\mathrm{MDA}=$ Malondialdehyde

Table 5: Effects of MEPT on the liver and kidney status of parasitized mice

\begin{tabular}{|c|c|c|c|c|c|c|c|}
\hline \multirow[t]{2}{*}{ Groups } & \multicolumn{4}{|c|}{ Biomarkers of liver status } & \multicolumn{3}{|c|}{ Biomarkers of liver status } \\
\hline & $\begin{array}{c}\text { AST } \\
\text { (IU/I) }\end{array}$ & $\begin{array}{l}\text { ALT } \\
\text { (IU/I) }\end{array}$ & $\begin{array}{c}\text { ALP } \\
\text { (IU/I) }\end{array}$ & $\begin{array}{c}\text { T. Bil } \\
\text { (mg/dl) }\end{array}$ & $\begin{array}{c}\text { Creatinine } \\
\text { (mmol/l) }\end{array}$ & $\begin{array}{l}\text { Urea } \\
(\mathrm{mg} / \mathrm{dl})\end{array}$ & $\begin{array}{c}\text { Uric acid } \\
(\mathrm{mmol} / \mathrm{l})\end{array}$ \\
\hline Group 1 & $59.00 \pm 4.32^{\mathrm{a}}$ & $11.75 \pm 0.96^{\mathrm{a}}$ & $22.00 \pm 8.60^{\mathrm{a}}$ & $0.70 \pm 0.08^{\mathrm{b}}$ & $0.88 \pm 0.07^{\mathrm{b}}$ & $24.00 \pm 0.82^{b}$ & $4.23 \pm 0.54^{\mathrm{a}}$ \\
\hline Group 2 & $79.00 \pm 3.16^{\mathrm{c}}$ & $25.75 \pm 1.71^{\mathrm{d}}$ & $37.00 \pm 1.83^{b}$ & $2.18 \pm 0.13^{\mathrm{d}}$ & $1.12 \pm 0.14^{\mathrm{c}}$ & $29.75 \pm 0.96^{\mathrm{c}}$ & $6.70 \pm 0.37^{\mathrm{c}}$ \\
\hline Group 3 & $66.50 \pm 2.65^{\mathrm{b}}$ & $14.25 \pm 1.26^{\mathrm{c}}$ & $24.25 \pm 0.96^{\mathrm{a}}$ & $1.00 \pm 0.08^{\mathrm{c}}$ & $0.76 \pm 0.08^{\mathrm{b}}$ & $20.75 \pm 0.96^{\mathrm{a}}$ & $4.58 \pm 0.19^{\mathrm{a}}$ \\
\hline Group 4 & $59.00 \pm 3.37^{\mathrm{a}}$ & $13.25 \pm 0.96^{\mathrm{b}}$ & $23.75 \pm 0.96^{\mathrm{a}}$ & $0.75 \pm 0.06^{\mathrm{b}}$ & $0.76 \pm 0.03^{b}$ & $21.00 \pm 0.82^{\mathrm{a}}$ & $4.40 \pm 0.22^{\mathrm{a}}$ \\
\hline Group 5 & $56.00 \pm 4.32^{\mathrm{a}}$ & $11.00 \pm 0.82^{\mathrm{a}}$ & $21.25 \pm 1.71^{\mathrm{a}}$ & $0.66 \pm 0.05^{\mathrm{a}}$ & $0.80 \pm 0.03^{\mathrm{b}}$ & $20.50 \pm 1.29^{\mathrm{a}}$ & $4.35 \pm 0.41^{\mathrm{a}}$ \\
\hline Group 6 & $54.50 \pm 4.20^{\mathrm{a}}$ & $12.75 \pm 0.96^{\mathrm{ab}}$ & $24.75 \pm 1.71^{\mathrm{a}}$ & $0.90 \pm 0.18^{\mathrm{c}}$ & $0.90 \pm 0.03^{b}$ & $25.00 \pm 0.82^{b}$ & $5.33 \pm 0.40^{\mathrm{b}}$ \\
\hline
\end{tabular}

Data were mean \pm standard deviation $(\mathrm{SD})(\mathrm{n}=4)$. Values with different superscript down the column are statistically significant at $\mathrm{p}<0.05$. AST $=$ Aspartate aminotransferase; $\mathrm{ALT}=$ Alanine aminotransferase; $\mathrm{ALP}=$ Alkaline phosphatase; T. Bil = Total bilirubin

3.6 Phytochemical constituents of MEPT

The presence of flavonoids, alkaloids, saponins, tannins, steroids, carotenoids, glycosides, anthraquinones, terpenoids and anthocyanins were detected in high amounts while phenols was detected in low amount in methanol extract of $P$. pterocarpum stem bark (Table 6).

Table 6: Phytochemical constituents of MEPT

\begin{tabular}{|l|l|}
\hline Phytochemicals & Bioavailability \\
\hline Saponins & +++ \\
\hline Tannins & +++ \\
\hline Alkaloids & +++ \\
\hline Flavonoids & +++ \\
\hline Glycosides & +++ \\
\hline Terpenoids & +++ \\
\hline Phenols & + \\
\hline Steroids & +++ \\
\hline Carotenoids & +++ \\
\hline Anthraquinones & +++ \\
\hline Anthocyanins & +++ \\
\hline
\end{tabular}

Key: $+++=$ high content; $++=$ moderate content; $+=$ low content

\section{Discussion}

The present study evaluated antimalarial activity and possible ameliorative effects of MEPT on the biochemical 
status of Plasmodium berghei Anka 65-parasitized mice. The reduction in malaria parasitaemia and increase in malaria parasite chemo-suppression by MEPT shows that it has antimalarial activity which is comparable with the standard artemisinin-combination therapy (ACT) antimalarial drug (arthemeter/lumenfantrin) used in this study. This finding agrees with our earlier report that methanol extract of this plant root has antimalarial activity and normalized malaria-modified haematological indices (Enechi et al., 2016). Bergenin, a sesquiterpene lactone compound, isolated from P. pterocarpum flowers has been shown to possess antimicrobial activity (Raj et al., 2012) while the antimalarial activity of berginin derived from Rodgersia aesculifolia Batal was reported (Liang et al., 2014).

Anaemia is a fairly common problem encountered in malaria. Czaja et al. (2002) reported that anaemic condition can be characterized by haemoglobin $(\mathrm{Hb})$ concentration of less than $13 \mathrm{~g} / \mathrm{dl}$. In the present study, the infected and untreated mice (group 2) had mean $\mathrm{Hb}$ concentration less than $13 \mathrm{~g} / \mathrm{dl}$ (indicating the presence of anaemia). The $\mathrm{Hb}$ concentration of group 2 mice was significantly $(\mathrm{p}<0.05)$ lower than that of the control (group 1). Treatment of the infected rats with graded doses of MEPT (groups 3-5) restored the Hb concentration relative to group 1 . The observed anaemia in $P$. berghei-infected mice may be due to RBC destruction caused either by parasite multiplication or by spleen reticuloendotelial cell action (Chinchilla et al., 1998). This decrease may also be due to repeated haemolysis of infected red cells is the most important. The haemolysis may be due to non-immune destruction of parasitized red cells in case of high parasitaemia as well as immune mediated destruction of parasitized as well as non-parasitized red blood cells. This is because changes in the red blood cell antigen structure brought about by the parasitic invasion may stimulate the production of antibodies against the red cell. This consequently triggers immune-mediated lysis of the red cell (Kotepui et al., 2014). In addition, the growing parasite consumes and degrades haemoglobin which may account for further decrease in $\mathrm{Hb}$. in the same vein, malaria infection has been shown to suppress erythropoiesis (Jadhav et al., 2004). These decreases however, were considerably reversed in the parasitized and MEPT as well as parasitized and artesunate-treated mice after $4^{\text {th }}$ day of treatment. This suggests that there may be total restoration in $\mathrm{Hb}$ and PCV levels and RBC counts, if monitored for further duration. The findings also suggest that the plant extract may have some stimulatory effect on the production of red blood cells which might have contributed to the increase in $\mathrm{Hb}$ concentration, PCV levels and WBC count as observed in the infected and MEPT-treated mice. More so, components of some plant extracts have been shown to boost erythropoiesis (Nwinuka et al., 2008). These results suggest that MEPT might be useful in managing anaemia. Leucopenia was observed in parasitized and untreated mice (group 2 mice). This agrees with the reports of Singh et al. (2014) that malaria induces anaemia, leucopenia, thrombocytopenia, and other haematological abnormalities. Malaria-induced thrombocytopenia might have resulted from either parasite antigen-programmed splenic destruction of platelets and/or suppression of thrombopoiesis by parasite antigen that infiltrates into the bone marrow (Morell, 2014; Srivastava et al., 2017). The increase in WBC of parasitized mice upon treatment with MEPT suggests that the extract is immunostimulatory in action. Similarly, the ability of the extract to increase the platelet count in the parasitized and extract-treated mice shows that is has stimulatory action on thrombopoiesis.

Parasitized and untreated mice had lower antioxidant enzymes (GPx, CAT and SOD) activities when compared with normal rats. The human endogenous antioxidant enzymes (such as GPx, GST, CAT and SOD) and non-enzymatic enzymes (such as GSH, a coenzyme required for GPx activity) makes up the inherent human antioxidant system which protects the cells from oxidative damages by scavenging free radicals responsible for oxidation of cellular components. SOD, a metalloprotein enzyme involved in antioxidant defense, acts by lowering the steady state level of superoxide anion radical $\left(\cdot \mathrm{O}_{2}^{-}\right)$, converting it to hydrogen peroxide $\left(\mathrm{H}_{2} \mathrm{O}_{2}\right)$ while CAT protects cells against radical toxicity by catalyzing the decomposition of $\mathrm{H}_{2} \mathrm{O}_{2}$ to water and molecular oxygen. During oxidative stress, as seen in malaria, free radical production is increased. Free radicals attack and damage cellular components, some of which are DNA, lipids, carbohydrates and proteins. When such damaged proteins are membrane proteins, receptors or even transport proteins, loss of function is bound to occur. Also, free radicals such as $\mathrm{H}_{2} \mathrm{O}_{2}$ attack thiol functional groups of side chain amino acids of enzymes, causing loss of enzyme activity. This could explain the reduced activity of the antioxidant enzymes as seen in the present study. Additionally, decreased levels of SOD and CAT in the malaria-infected and untreated mice may be due to the overuse of these enzymatic antioxidants to control malarial-induced free radical production.

The level of lipid peroxidation is an indication of membrane damage; alterations in its structure and function, and is measured by the level of MDA. Erythrocytes are more vulnerable to lipid peroxidation due to high unsaturated fatty acid content of the membrane and lower antioxidant capacity (Anandan et al., 1999). A significantly higher mean MDA level was observed in the parasitized and untreated mice (group 2) when compared with normal mice (group 1). This result suggests the existence of oxidative stress in malaria. Oxidative stress may have resulted from the release of intermediates of plasmodial attack on cellular components, and breakdown products of haemoglobin such as heme and free ferrous ion. These products are free radicals and free radical-producing agents (via Fenton and Harber-Weiss reactions) respectively. The reduction in activities of antioxidant enzymes in group 2 mice when compared with group 1 could also be due to the cross-linking of these 
enzymes with MDA (Eritsland et al., 2000). Reports have suggested the existence of oxidative stress in malaria; markers of oxidative stress were found to be elevated in infected humans and rodents compared to uninfected controls (Sobolewski et al., 2005; Cabrales et al., 2011). This reinforces the suggestion that oxidative stress plays a major role malaria infection and its associated complications. Also, cells of host immune system (phagocytes) produce free radicals to attack and kill malaria parasite during invasion. Some of these free radicals produced, especially hydrogen peroxide, can travel from the point of production to other sites, causing cellular damage to both the host and foreign cells (Cabrales et al., 2011). Treatment of parasitized mice with extract and standard drug for 4 days significantly $(\mathrm{p}<0.05)$ reduced the percentage malaria parasitaemia and reduced MDA concentrations, and increased malaria parasite chemo-suppression and antioxidant enzymes activities towards the normal control. This implies that the extract has antimalarial and antioxidant activities.

Malaria infection resulted in lower concentrations of antioxidant vitamins (vitamins $\mathrm{A}, \mathrm{C}$ and $\mathrm{E}$ ) as seen in parasitized and untreated mice when compared with normal control. The lower values observed in antioxidant vitamin levels in malaria may be attributed to increased utilization of the hosts serum antioxidants by malaria parasites to counteract oxidative damage (Akpotuzor et al., 2007). It may also be linked to the mobilization of such antioxidants to scavenge free radicals produced during malaria invasion by the host cells. Report also showed that antioxidants such as carotenoids, vitamins $\mathrm{C}$ and $\mathrm{E}$ could provide protection against oxidative stress induced by malaria (Adelekan et al., 1997) and hence, may be lowered during malaria infection. It was observed that the higher the level of parasitaemia, the lower the concentrations of these antioxidant vitamins. Treatment of parasitized mice with methanol extract and standard drug significantly $(p<0.05)$ increased the antioxidant vitamins concentrations towards normal control mice when compared to infected and untreated mice. The implication of this finding is that MEPT, which has exhibited both antioxidant and antimalarial effects, may be better option in managing of malaria. Our findings also suggest that inclusion of antioxidant agents as one of the regimen drugs particularly vitamin $\mathrm{C}$ because of its ability to act even in lipid and water medium as well as its availability and affordability may be quite beneficial in treatment of malaria patients. However, this must be done after treatment with antimalarial drug to avoid counter reaction. Further study to verify this approach, especially days after malaria treatment is warranted.

The pathogenesis of this parasite infection involves the liver stage where sporozoites invade and multiply in hepatocytes and an erythrocyte stage where merozoites cause the destruction of the infected red blood cells prior to their differentiations into male and female gametocytes. This leads to significant alterations in host hepatocyte physiology and morphology (Strickland, 1991). The increase in serum ALT, AST and ALP activities in parasitized and untreated mice when compared with those of normal control in this study shows that malaria parasite infection may be responsible for the increase in the activities of the liver enzymes, which may lead to liver dysfunction. Our result agrees with previous reports that plasmodial infection increase serum liver enzymes activities (Onyesom, 2012; Akambi, 2015). The elevated enzymes activities correlate with level of parasitaemia, which suggests that the level of liver dysfunction may be determined by the level of parasitaemia. This study agrees with the previous study which showed a positive correlation between the level of liver dysfunction and parasitaemia (Onyesom and Onyemakonor, 2011).

The invasion and development of the malaria parasite into the liver during the life cycle may be responsible for liver dysfunction by causing membrane damage, resulting in enzyme leakage, organ congestion, cellular inflammation, and sinusoidal blockage (Anyasor and Olorunsogo, 2011). Chikezie and Okpara (2013) showed the presence of hepatic dysfunction in malaria infection. Malaria parasitaemia engenders increased red blood cell haemolysis, which is associated with increase in bilirubin biosynthesis, hepatocellular damage, biliary tract obstruction and jaundice (Yokoto and Elisei, 2006). Higher total bilirubin concentration was observed in the parasitized and untreated mice when compared with those of normal and parasitized MEPT/standard drug-treated mice. The observed high serum bilirubin level indicates the possibility of intrahepatic cholestasis. Centribular damage in acute malaria infection is the major cause high serum bilirubin level, an indication of loss of drainage action by the liver (Yokoto and Elisei, 2006).

Accumulation of both conjugated and unconjugated bilirubin and bile acid is implicated in the development acute renal failure (ARF) in malaria (Prakash et al., 1996). Meanwhile, treatment of parasitized mice with MEPT and standard drug significantly $(\mathrm{p}<0.05)$ decreased the activities of liver function enzymes (ALT, AST and ALP) and concentration of total bilirubin in serum when compared with infected and untreated mice. This suggests that MEPT possess hepatocurative and ameliorative effect on hepatic dysfunction induced by malaria infection. Malaria parasitized and untreated mice had significantly $(\mathrm{p}<0.05)$ higher serum concentrations of renal function markers (creatinine, urea and uric acid) when compared with normal mice. The observed increase in creatinine, urea and uric acid in the parasitized and untreated group could be a result of sequestration of the parasite into the renal microvasculature bed which may lead to ischemia (Zaki et al., 2013). This indicates that mice with hyperparasitaemia may be more likely to have transient renal dysfunction which could be limited for the period of the infection. The elevated serum creatinine, urea ad uric acid may be due to accumulation as a result of reduction in the clearance during acute malaria infection by the affected kidneys which may return to normal levels after 
recovery (Mishra et al., 2007). The severity ARF, one of the serious complications of malaria is dependent of the level of parasitaemia; ARF in malaria is observed only in subjects with heavy parasitaemia (Boonpucknavig and Sitprija, 1979). Parasitized erythrocytes are rigid and have decreased deformability leading to slower flow in the microcirculation. Viscosity of parasitized RBCs is also increased leading to increased viscosity of whole-blood (Prakash et al., 1996). Findings of these study showed that treatment of parasitized mice with MEPT (groups 3-5) and standard drug (group 6) significantly $(\mathrm{p}<0.05)$ decreased the concentrations of renal function markers (creatinine, urea and uric acid) when compared to those of parasitized and untreated mice (group 2). This suggests that the methanol extract possess nephrocurative effect on renal dysfunction induced by malaria infection.

Natural polyphenols from plants have been found to scavenge free radicals, chelate metal ions that participate in Fenton-type reaction and activate antioxidant enzymes (Ayoola et al., 2008). Alkaloids and saponins have been shown to bacteriocidal, antiplasmodial and antispasmodic effects (Tarawneh et al., 2010). The antimalarial activity and ameliorative effects of MEPT on malaria-induced biochemical alterations in this study could be attributed to the phytochemical constituents such as alkaloids, flavonoids, steroids among others detected in the extract. Some of these phyto-constituents have been shown to possess antimalarial and antioxidant activities (Chierrito et al., 2014), and modulatory effects on nephrotoxicity and hepatotoxicity.

\section{Conclusion}

In general, findings from the present study demonstrated that methanol extract of $P$. pterocarpum stem bark (MEPT), in addition to its antimalarial activity, normalized oxidative stress, lipid peroxidation, and kidney and liver abnormalities induced by Plasmodium berghei Anka-65 infection. The active pharmacological principles in MEPT need to be isolated and subjected to clinical trials for malaria treatment. This may provide leads for the development of new antimalarial drug.

Conflict of interest: Authors declare none

\section{References}

Adelekan, D.A., Adeodu, O.O., \& Thurnham, A. (1997). Comparative effect of malaria and malnutrition on plasma antioxidant vitamins in children. Ann Trop Paediatr., 17, 223-227.

Aebi, H., (1984). Catalase. In: Bergmeyer, H.L, editor. Methods in Enzymatic Analysis. Cheime, Weinheim, New York: Academic Press, pp. 674-684.

Akanbi, O.M., (2015). The influence of malaria infection on kidney and liver function in children in Akoko area of Ondo State, Nigeria. J Parasitol Vector Biol., 7(8), 163-168.

Akin-Osanaiye, B.C., Nok, A.J., Ibrahim, S., Inuwa, H.M., Onyike, E., Amlabu, E., \& Haruna, E. (2013). Antimalarial effect of neem leaf and neem stem bark extracts on Plasmodium berghei infected in the pathology and treatment of malaria. IJRBB, 3(1), 7-14.

Akpotuzor, J.O., Udoh, A.E., \& Etukudo, M.N., (2007). Total antioxidant status, vitamins A, C and $\beta$-Carotene levels of children with $P$. falciparum infection in University of Calabar Teaching Hospital (UCH), Calabar. PJN., 6(5), 485-489.

Anandan, R., Rekha, R.D., \& Devaki, T., (1999). Protective effect of Picrorhiza kurroa on mitochondrial glutathione antioxidant system in D-galactosamine-induced hepatitis in rats. Curr Sci., 76(12), 1543-1545.

Anyasor, G.N., \& Olorunsogo, O.O., (2011). Evaluation of selected biochemical parameters in renal and hepatic functions following oral administration of standard drug to albino mice. Researcher, 3(7), 30-34

Ayoola, G.A., Coker, H., Adesegun, S.A., Adepoju-Bello, A.A., Obaweya, K., \& Ezennia, E.C. (2008). Phytochemical screening and antioxidant activities of some selected medicinal plants used for malaria therapy in South-western Nigeria. TJPR., 7(3), 1019-1024.

Bakhubaira, S. (2013). Hematological parameters, severe complicated Plasmodium falciparum malaria among adults in Aden. Turk J Haematol., 30, 394-399.

Biswas, A., Kumar, A., Babaria, B.A., Prabhu, K., \& Ramachandra, S.S. (2010). Hepatoprotective effect of leaves of Peltophorum pterocarpum against paracetamol-induced acute liver damage in rats. $J$ Basic Clin Pharm., 1(1), 10-15.

Boonpucknavig, U., \& Sitprija, V. (1979). Renal disease in acute Plasmodium falciparum infection in man. Kidney Int., 16, 44-52.

Burtis, E., \& Ashwood, B. (2001). Liver functions. In: Tietz Fundamentals of Clinical Chemistry, $5^{\text {th }}$ ed. Philadelphia: Saunders Company, pp. 748-770.

Cabrales, P., Zanini, G.M., Meays, D., Frangos, J.A., \& Carvalho, L.J.M. (2011). Nitric oxide protection against murine cerebral malaria is associated with improved cerebral microcirculatory physiology. $J$ Infect Dis., 203, 1454-1463

Chierrito, T.P.C., Aguiar, A.C.C., de Andrade, I.M., Ceravolo, I.P., Gonçalves, R.A.C., de Oliveira, A.J., \& Krettli, A.U. (2014). Anti-malarial activity of indole alkaloids isolated from Aspidosperma olivaceum. 
Malaria Journal, 13: 142. http://www.malariajournal.com/content/13/1/142

Chikezie, C.P., \& Okpara, R.T. (2013). Haematologic and biochemical indices of Plasmodium falciparum infected inhabitants of Owerri, Imo State, Nigeria. $J M L D, 4(3), 38-44$.

Chinchilla, M., Guerrero, O. M., Abarca, G., Barrios, M., \& Castro, O., (1998).An in vivo model to study the antimalaric capacity of plant extracts. Journal of Revised Biological Tropical, 46(1), 35-39.

Czaja, J.A., Peter, T.D., \& Ansgar, N.L., (2002). Antibiodies to soluble antigen/liver pancrease and HLA risk factors for type 1 autoimmune hepatitis. The America Journal of Gastroenterology, 93, 413-419

Desai, I.D. (1984). Vitamin E analysis: methods for animal tissues. Methods Enzymol., 105, 138-147.

Dzeing-Ella, A., Pascal, C., Obiang, N., Tchoua, R., Planche, T., Ebele, J.I., Emeka, E.N., Nnenna, C.A., Ignatius, C.M., \& Ebele, A. (2010). Severe Falciparum malaria in Gabonese children: clinical and laboratory features. Malar J., 4, 1-8.

Elased, K., \& Playfair, J.H. (1994). Hypoglycemia and hyperinsulinemia in rodent models of severe malaria infection. Infect Immun., 62, 5157-5160.

Enechi, O.C., Egbujionuma, C.E., Ogugua, V.N., \& Okagu, I.U. (2016). Antiplasmodial activity and amelioration of altered haematological indices by methanol extract of Peltophorum pterocarpum in Plasmodium berghei-infected mice. Glob Vet., 16(5), 491-499.

Eritsland, J. (2000). Safety considerations of polyunsaturated fatty acids. Am J Clin Nutr., 71(S1), $197-201$.

Fawcett, J.K., \& Scott, J.E. (1960). A rapid and precise method for the determination of urea. J Clin Pathol., 13, 156-159.

Fridovich, I. (1983). Superoxide dismutase: an adaptation to a paramagnetic gas. J Biol Chem., 204, 7761-7764.

Gomes, A.P., Vitorino, R.R., Costa, A., de Mendonça, E.G., Oliveira, M.G.A., \& Siqueira-Batista, R. (2011). Severe Plasmodium falciparum malaria. Rev Bras Ter Intensiva., 23, 358-369.

Goodhart, R.S., \& Shils, M.E., (1973). Modern Nutrition in Health and Disease Dictotherapy. UK: Lea and Febiger, pp. 245-253.

Habig, W.H., Pabst, M.J.M., \& Jakoby, W.B. (1974). Glutathione-S-transferases. The first enzymatic step in mercapturic acid formation. J Biol Chem., 249(22), 7130-7139.

Harborne, J.B. (1973). Phytochemical Methods. Chapman and Hall Limited, London. pp. 49-88.

Henry, R. (1974). Clinical Chemistry: Principles and Technics. $4^{\text {th }}$ ed. New York: Hoeber, p. 297.

Jadhav, U.M., Patkar, V.S., \& Kadam, N.N. (2004). Thrombocytopenia in malaria- correlation with type and severity of malaria. $J$ Assoc Physicians India, 52, 615-618.

Jagessar, R.C., Mohamed, A., \& Gomes, G. (2007). Antibacterial and antifungal activity of leaf extracts of Luffa operculata, Peltophorum pterocarpum against Candida albicans, Staphylococcus aureus and E. coli. Nat Sci., 5(4), 56-59.

Jain, S.C., Bosky, P., \& Renuks, J. (2012). Antimicrobial, free radical scavenging activities and chemical composition of Peltophorum pterocarpum stem extract. J Med Chem., 4(5), 2073-2079.

Jarikre, A.E., Emuveyon, E.E., \& Idogun, S.F. (2001). Pitfalls in the interpretations of liver parenchymal and membraneous enzyme results in preclinical $P$. falciparum and malaria in the Nigerian environment. Niger $J$ Clin Pract., 4(1), 19-21.

Jasani, J.H., Sancheti, S.M., Gheewala, B.S., Bhuva, K.V., Doctor, V.S., \& Vacchani, A.B. (2012). Association of electrolyte disturbances $\left(\mathrm{Na}^{+} / \mathrm{K}^{+}\right)$with type and severity of malarial parasitic infection. $J$ Clin Diagn Res., 6(S2), 678-681.

Jendrassik, J., \& Grof, P. (1938). In-vitro determination of total and direct bilirubin in serum or plasma. Biochem., 6, 269-275

Karunai, M., RaJ, V., Duraipandiyan, P., Agastian, S., \& Ignacimuthu, H. (2012). Antimicrobial activity of bergenin isolated from Peltophorum pterocarpum (DC) flowers. Asian Pacific Journal of Tropical Biomedicine, 5(12), 56-60.

Kochmar, G.F., \& Moss, D.W. (1976). Fundamentals of Clinical Chemistry. Tietz, N.W. Editor. Philadelphia: Sunders and Company, pp. 604-610.

Kotepui, M., Phunphuech, B., Phiwklam, N., Chupeerach, C., \& Duangmano, S. (2014). Effect of malarial infection on haematological parameters in population near Thailand-Myanmar border. Malaria Journal, 13: 218. doi:10.1186/1475-2875-13-21.

Liang, J., Li, Y., Liu, X., Huang, Y., Shen, Y., Wang, J., Liu, Z., \& Zhao, Y. (2014). In vivo and in vitro antimalarial activity of bergenin. Biomedical Reports, 2, 260-264.

Manaharan, T., Teng, L.L., Appleton, D., Ming, C.H., Masilamani, T., \& Palanisamy, U.D. (2011). Antioxidant and antiglycemic potential of Peltophorum pterocarpum plant parts. Food Chem., 129, 1355-1361.

Milena, J., Pedrag, D., \& Dejan, S. (2003). Determination of uric acid in human serum by an enzymatic method using N-methyl-N-(4-aminophenyl)-3-methoxyaniline reagent. J Serb Chem Soc., 68(8-9), 691-698.

Mishra, S.K., Dietz, K., Mohanty, S., \& Pati, S.S. (2007). Influence of acute renal failure in patients with cerebral malaria; a hospital-based study from India. Trop Doct., 37, 103-104. 
Morrell, C.N. (2014). Understanding platelets in malaria infection. Curr Opin Hematol., 21(5), 445-449.

Naqvi, R., Ahmad, E., Akhtar, F., Naqvi, A., \& Rizvi, A. (2003). Outcome in severe acute renal failure associated with malaria. Nephrol Dial Transplant., 18, 1820-1823.

Nwinuka, N.M., Monanu, M.O. \& Nwiloh, B.I. (2008). Effects of aqueous extract of Mangifera indica L.

(Mango) stem bark on haematological parameters of normal albino rats. Pakistan Journal of Nutrition, 7(5), 663-666.

Ogbadoyi, E.O., \& Tsado, R.D. (2009). Renal and hepatic dysfunction in malaria patients in Mina, North Central Nigeria. OJHAS, 8, 2-6.

Onaku, L.O., Attama, A.A., Okore, V.C., Tijani, A.Y., Ngene, A.A., \& Esimone, C.O. (2011). Antagonistic antimalarial properties of pawpaw leaf aqueous extract in combination with artesunic acid in Plasmodium berghei-infected mice. J Vector Borne Dis., 48, 96-100.

Onyesom, I., \& Onyemakonor, N. (2011). Levels of parasitaemia and changes in some liver enzymes among malarial infected patients in Edo-Delta region of Nigeria. Cur Res J Bio Sci., 3, 78-81.

Onyesom, I. (2012). Activities of some liver enzymes in serum of $P$. falciparum malarial infected humans receiving artemisinin and non-artemisinin-based combination therapy. Anal Bio Res., 3, 3097-3100.

Oyewolea, I.O., Anyasorb, G.N., Ainac, O.O., Ogunnowod, A. A., Sorinwae, B.A., \& Abraham, B.E. (2014). Parasitemia and antimalarial-induced histological alterations and oxidative stress in infected mice. Scientific Journal of Biological Sciences, 3(5), 38-46.

Padhi, R.K., \& Mishra, S, (2012). Incidence of renal involvement in malaria in children of Odisha. ISRN Nephrol, 2012, Article ID 573735.

Paglia, D.E., \& Valentine, W.M. (1962). Studies on the quantitative and qualitative characterization of erythrocyte glutathione peroxidase. J Lab Clin Med., 70, 158-169.

Peters, W. (1967). Rational methods in the search for antimalarial drugs. Transactions of the Royal Society, 61, 400-410.

Prakash, J., Gupta, A., Kumar, O., Rout, S.B., Malhotra, V., \& Srivastava, P.K. (1996). Acute renal failure in falciparum malaria- increasing prevalence in some areas of India - a need for awareness. Nephrol Dial Transplant., 11, 2414-2416.

Raj, M.K., Duraipandiyan, V., Agustin, P. \& Ignacimuthu, S. (2012). Antimicrobial activity of bergenin isolated from Peltophorum pterocarpum DC. flowers. Asian Pac J Trop Biomed., 2, 901-904.

Ravikumar, A., \& Subbu-Raltinan, K.M. (2009). Antibacterial activity of hexane and acetone extracts of Peltophorum pterocarpum. Int J Chem Sci., 7(3), 1751-1756.

Reitman, S., \& Frankel, S. (1957). A colorimetric method of determination of serum levels of glutamic, oxaloacetic acid and pyruvic acid transaminases. Am J Clin Pathol., 10, 394-399.

Saotoing, P., Vroumsia, T., Tchobsala, T., Fohouo, F., Njan, N., Alexandre, M., \& Messi, J. (2011). Medicinal plants used in traditional treatment of malaria in Cameroon. J Ecol Nat Environ., 3(3), 104-117.

Singh, G., Urhekar, A.D., Maheshwari, U., \& Sharma, S. (2014). Effects of malarial parasitic infections on human blood cells. International Journal of Current Microbiology and Applied Sciences, 3(12), 622-632.

Sobolewski, P., Gramaglia, I., Frangos, J.A., Intaglietta, M., \& Heyde, H.V.D. (2005). Plasmodium berghei resists killing by reactive oxygen species. Infect Immun., 73, 6704-6710.

Srivastava, K., Sharma, M., \& Mitchell, W.B. (2017). Malaria and thrombopoiesis: A possible mechanism for the malarial thrombocytopenia. Journal of Immunology, Infection and Inflammatory Diseases, 2(1), 014.

Strickland, G.T. (1991). Life cycle of malaria parasite. In: Tropical Medicine. $7^{\text {th }}$ Ed. USA: W.B. Saunders, pp. 586-601.

Tarawneh, K.A., Irshaid, F., \& Jaran, A.S. (2010). Evaluation of antibacterial and antioxidant activities of methanolic extracts of some medicinal plants in Northern part of Jordan. J. Bio. Sci., 10(4), 325-332.

Trease, G.E., \& Evans, W.C., (1989). Pharmacognosy. $11^{\text {th }}$ Edn. Saunder Publishers, London. pp. 42-44, 221229, 246-249, 404-306, 331-332, 391-393.

Uzuegbu, U.E. (2011). Serum electrolytes and urea changes in P. falciparum malarial infected children in Nigeria. Asian J Med Sci., 3, 50-51.

Wallin, B., Rosengren, B., Shetzer, H.G., \& Camejo, G. (1993). Lipoprotein oxidation and measuring of thiobarbituric acid reacting substances (TBARS) formation in a single microtitre plate: its use for evaluation of antioxidants. Anal Biochem., 208, 10-15.

World Health Organization (WHO) (2018). World Malaria Report. Geneva. www.who.int/news-room/factsheets/detail/malaria. Retrieved on $5^{\text {th }}$ November, 2018.

Yokoto, K.S.C., \& Elisei, C. (2006). Malaria parasites (Apicomplexa, Haematozoea) and their relationships with their hosts: is there an evolutionary cost for the specialization? JZS, 44(4), 265-273.

Zaki, H.Y., Abdalla, B.E., \& Hayder, B. (2013). Biochemical Profiles of Children with Severe Plasmodium falciparum malaria in central Sudan: A case control study. Al Neelain Med J, 3, 15-23. 